Human palaeontology and prehistory

\title{
New data and provenance of obsidian blocks from Middle Neolithic contexts on Corsica (western Mediterranean)
}

\section{Nouvelles données et provenance de blocs d'obsidienne de contextes Néolithique moyen de Corse}

\author{
François-Xavier Le Bourdonnec ${ }^{\mathrm{a}, *}$, Gérard Poupeau ${ }^{\mathrm{a}, \mathrm{b}}$, Carlo Lugliè ${ }^{\mathrm{c}}$, André D’Anna $^{\mathrm{d}}$, \\ Ludovic Bellot-Gurlet ${ }^{\mathrm{e}}$, Céline S. Bressy-Leandri ${ }^{\mathrm{c}}$, Alain Pasquet ${ }^{\mathrm{f}}$, Pascal Tramoni ${ }^{\mathrm{d}, \mathrm{g}}$ \\ a IRAMAT-CRP2A, UMR 5060, CNRS-université Bordeaux, 3, maison de l'Archéologie, Esplanade-des-Antilles, 33607 Pessac, France \\ b Département de préhistoire et UMR 7194, CNRS-Muséum national d'histoire naturelle, centre de spectroscopie infrarouge, \\ 57, rue Cuvier, 75231 Paris cedex 05, France \\ c Dipartimento di Scienze Archeologiche e Storico-Artistiche, Università di Cagliari, Cagliari, Italy \\ d LAMPEA, université de Provence-CNRS-MCC-IRD (UMR 6636), maison Méditerranéenne des sciences de l'homme, \\ 5, rue du château de l'horloge, BP 647, 13094 Aix-en-Provence cedex 2, France \\ e Laboratoire de dynamique, interactions et réactivité (LADIR) UMR 7075, CNRS et UMPC, université Pierre-et-Marie-Curie Paris 6, \\ 2, rue Henri-Dunant, 94320 Thiais, France \\ f Padulaccia Suttana, 20137 Lecci-de-Porto-Vecchio, Italy \\ g INRAP Méditerranée, 561, avenue Étienne-Lenoir, 30900 Nîmes, France
}

\section{A R T I C L E I N F O}

\section{Article history:}

Received 9 July 2010

Accepted after revision 29 December 2010

Available online 1 March 2011

Presented by Philippe Taquet

\section{Keywords:}

Obsidian blocks

Provenance

PIXE

Neolithic

Corsica

\begin{abstract}
A B S T R A C T
The provenance of twelve un-worked blocks and one part-knapped block recovered from the surface of five Middle Neolithic sites in the vicinity of Porto Vecchio, southeastern Corsica (western Mediterranean), was determined by ion beam analysis (PIXE). This is the first such discovery on Corsica of actual raw blocks of this exotic material. Twelve of these samples come from sources associated with the Monte Arci volcanic complex of CentralWest Sardinia, with six each of the SA and SC chemical types. The only possible origin for the remaining block is Lipari, a raw material previously only attested by three artifacts from a Neolithic site of NW Corsica. This piece is aberrant for its unusual facies and its poor quality, making it quite unsuitable for knapping, and by extent distinct from the high quality glassy obsidian from Lipari that was used regularly by Neolithic peoples. This raises the question of the archaeological significance of this surface find.
\end{abstract}

(c) 2011 Académie des sciences. Published by Elsevier Masson SAS. All rights reserved.

\section{R É S U M É}

La provenance de douze blocs bruts d'obsidienne et d'un treizième tout juste testé, trouvés en surface dans cinq contextes du Néolithique moyen du Sud-Est de la Corse, à proximité de Porto Vecchio, a été déterminée par analyse élémentaire sous faisceau d'ions (PIXE). Ces blocs, d'un matériau dont il n'existe aucune source sur l'île, sont actuellement les seules trouvailles de ce type. Douze de ces obsidiennes proviennent de zones-sources associées au massif du Monte Arci (centre-ouest de la Sardaigne),
Blocs d'obsidienne

Provenance

PIXE

Néolithique

Corse

\footnotetext{
* Corresponding author.

E-mail addresses: Francois-Xavier.Le-Bourdonnec@u-bordeaux3.fr (F.-X. Le Bourdonnec), gpoupeau@mnhn.fr, gpoupeau@u-bordeaux3.fr

(G. Poupeau), luglie@unica.it (C. Lugliè), danna@mmsh.univ-aix.fr (A. D’Anna), bellot-gurlet@glvt-cnrs.fr (L. Bellot-Gurlet), cbressy@mmsh.univ-aix.fr (C.S. Bressy-Leandri), pascal.tramoni@inrap.fr (P. Tramoni).
} 
dont respectivement six de chacun des types de composition chimique SA et SC. Un treizième bloc, n'a pu venir que de lî̀le de Lipari, une origine connue pour seulement trois autres obsidiennes d'un site néolithique corse, situé dans le Nord-Ouest de la Corse. Son faciès inhabituel et peu propice à la taille ne correspond pas au verre volcanique liparote de grande qualité, utilisé par les néolithiques, ce qui pose la question de sa pertinence archéologique.

@ 2011 Académie des sciences. Publié par Elsevier Masson SAS. Tous droits réservés.

\section{Introduction}

Obsidian is frequently found at Neolithic sites of the western Mediterranean. Many studies since the 1960s have shown that the origin of this material is limited to the four island sources of Lipari, Palmarola, Pantelleria and Sardinia (Arias et al., 2006; Bigazzi and Radi, 1998; Cann and Renfrew, 1964; Hallam et al., 1976; Lugliè, 2009; Tykot, 1996, inter alia), which makes this material a good index of regional contact and exchange between local communities over several millennia (Fig. 1). In Corsica, obsidian artefacts first appeared during the early 6 th millennium $B C$ with the earliest settlements of the Cardial culture (Atzeni, 1966; Bailloud, 1969; Camps, 1988; Costa, 2006; D’Anna et al., 2001; Lanfranchi, 1980). Flint, another exotic material whose closest sources lay in Sardinia, also played an important role in stone tool production of an island poor in local rocks of good knapping qualities (Bressy et al., 2003, 2007, 2008; Marini et al., 2007), with local resources largely limited to rhyolites (Ameziane-Federzoni, 2007a, 2007b; Costa et al., 2002) and quartz. Since the 1970s, a number of provenance studies have shown that the obsidian found on Corsica came from Sardinian sources (e.g. Bigazzi et al., 2005; Bressy et al., 2008; Hallam et al., 1976; Le Bourdonnec et al., 2010a; Tykot, 1996), with the exception of one sample sourced to Palmarola (Salotti et al., 2000) while two others came from Lipari (Le Bourdonnec et al., 2010a). Of the four chemical types of Sardinian obsidians, all associated with the Monte Arci volcanic complex, only one type (SB1) is almost completely absent from these Corsican lithic assemblages.

The modes of obsidian acquisition by Corsican populations are still poorly understood, in particular the form in which the obsidian was 'imported'. Although evidence for obsidian knapping is known from a few sites on Corsica, such as Tivulaghju (Tramoni et al., 2007), Vasculacciu (Tramoni et al., 2003, 2004) and Campu Stefanu (Cesari et al., 2011), in the southern part of the island, or A Fuata in the north-west (Le Bourdonnec et al., 2010a), cores are otherwise generally lacking, or poorly represented in most assemblages. It currently remains uncertain as to whether this is a reflection of intense local reduction strategies (whereby it is now impossible to recognize the cores), or indicative of these communities procuring part-/ready-made products (Costa, 2006). Until the last few years, non-worked obsidian blocks or pebbles were unknown in Corsica. However, twelve such blocks and another one only tested were recently discovered in the southern part of the island, a region known to have been in close cultural connection with Sardinia during much of the Neolithic, from the 6-4th millenium BC (Tramoni et al., 2007). It is the purpose of this paper to characterize these blocks and to evaluate their importance in the context of regional procurement strategies.

\section{The obsidian blocks and their contexts}

All the obsidian blocks were collected in the south-east of Corsica, in the vicinity of the coastal city of Porto Vecchio. They were all found on the surface of five Neolithic sites: I Caselli and Foce ( 8 and $9 \mathrm{~km}$ to the north-east of Porto Vecchio) plus Tivulaghju, Vasculacciu and Teghja di Donna (3, 10 and $11 \mathrm{~km}$ respectively to the city's south-west Fig. 1). From their visual characteristics twelve of these obsidians were attributed a Sardinian origin, while a Lipari provenance was tentatively assigned to the remaining sample (Table 1).

Eight blocks came from the megalithic site of Tivulaghju, or 'Tivolaggio', located on the left bank of an alluvial terrace along the lower Stabbiaccu river valley. While the site was first described during the 1960s (Grosjean, 1961; Grosjean and Liegeois, 1964) it was only in the early 2000 that detailed investigations of the megalithic monuments and their surroundings were initiated (Tramoni et al., 2007). The site is composed of two megalithic cist burials together with numerous other anthropogenic remains dispersed over an area of about $25,000 \mathrm{~m}^{2}$, amongst which are four loci with notable artifact concentrations (Tramoni et al., 2007, Fig. 5). These include obsidian and flint, with 1989 and 129 artifacts respectively, (which comprise $87 \%$ of the chipped stone materials), plus more than 1000 bones and 600 potsherds fragments. The typo-technological characteristics of the Middle Neolithic stone tools, and the pots' shapes and decorations, are typical of the second half of the 5 th millennium BC. In locus 1 , a group of seven obsidian blocks were found in a group, suggesting that they had originally been stored together in a cache (Fig. 2). Weighing between 111 and $438 \mathrm{~g}$, the largest dimension of these blocks was between 67 to $113 \mathrm{~mm}$ which is comparable to the initial module sizes estimated from the local obsidian debitage products (Tramoni et al., 2007).

One block comes from Vasculacciu, among the bestdocumented megalithic site of Corsica, known since the 19th century (Fig. 3 ). In a preliminary examination seven megalithic cist burials were identified and partly excavated (Grosjean, 1961; Grosjean and Liegeois, 1964) while an eighth was identified during a later re-examination of the site (Lanfranchi, 1986), while two more structures were unearthed during the early 2000 (Tramoni et al., 2004). Vasculacciu is situated on the top of a hill about halfway between the southwestern coast and the Figari gulf (Tramoni et al., 2004, Fig. 2). The excavated part 


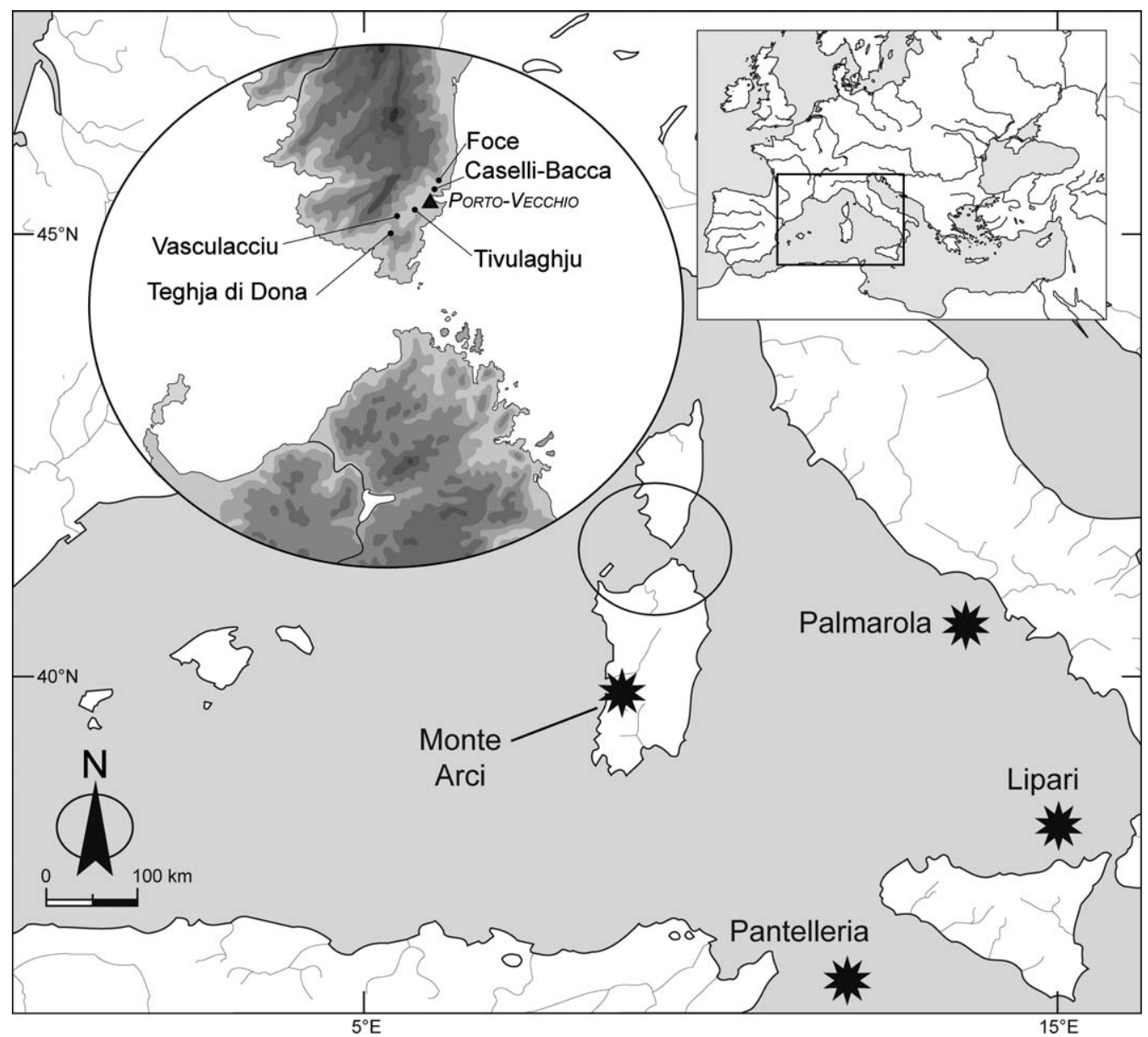

Fig. 1. Schematic map of western Mediterranean showing its four obsidian island-sources and the localization of the blocks-bearing sites in southern Corsica.

Fig. 1. Carte schématique de la Méditerranée occidentale montrant la localisation des îles-sources d'obsidienne et en Corse méridionale celle des sites où ont été trouvés les blocs analysés.

of the necropolis occupies an area of $2000 \mathrm{~m}^{2}$ (Tramoni et al., 2004, Fig. 3); $200 \mathrm{~m}$ to the south-west lay the two megalithic burials of the Urgonu site (Grosjean, 1961; Tramoni et al., 2004, Fig. 4). Remains of a Neolithic occupation are attested by thousands of surface finds around the Vasculacciu monuments, with the three loci of highest concentrations within less than $100 \mathrm{~m}$ of the necropolis. It is not certain that the monuments and open-air settlement were contemporaneous but this kind of monument is unknown elsewhere in Corsica before $4800 \mathrm{cal}$ $\mathrm{BC}$ and the rather typologically homogeneous Vasculacciu lithic/ceramic industry suggests a Middle Neolithic date no younger than $3800 \mathrm{BC}$ (Tramoni et al., 2007) as confirmed by ${ }^{14} \mathrm{C}$ ages of $4600-4200 \mathrm{cal} \mathrm{BC}$. The Vasculacciu block was found on a small hill $200 \mathrm{~m}$ from the necropolis and inside the perimeter of an associated Neolithic settlement.

The I Caselli and Foce sites are situated downslope from the Tozze Bianche mound, on its southern and eastern margins respectively. Both are extended surface scatters where the spatial distribution of the numerous finds suggests activity/settlement in several loci (Pasquet, 1979;
Tramoni, 2000). I Caselli is situated on the left bank of the Osu coastal plain, some $500 \mathrm{~m}$ from the coast of the San Cipriano Bay. Here hundreds of obsidian artifacts, including numerous non-retouched blades, are distributed over an area of $5000 \mathrm{~m}^{2}$, while obsidian flakes are also found on the slopes surrounding the site. Most of the numerous associated ceramics can be attributed to the Basian Neolithic, which dates this site to the 4 th millennium BC. Two obsidian blocks were found by an amateur collector within the general spread of the I Caselli artifacts. Foce appears to be an important open air settlement on the upper edge of a granitic alveoli, with artifacts spread across almost five hectares. As at I Caselli, obsidian is abundant. On the basis of the ceramic and lithic industry, this site can be attributed to the Middle Neolithic, locally dated to the end of the 5th millennium. The Foce obsidian block comes from the Truscietu locus.

The Teghja di Donna block, also found by an amateur archaeologist, was collected in the southern part of the Sotta village territory in an elevated site relatively poor in archaeological remains. Its association to nearby finds 
Table 1

Samples origin and macroscopic characterization.

Tableau 1

Origine et caractérisation macroscopique des échantillons.

\begin{tabular}{|c|c|c|c|c|c|c|}
\hline Site & Origin & Sample ref. & Mass (g) & Nature & Description & Type \\
\hline \multirow[t]{2}{*}{$\begin{array}{l}\text { Caselli- } \\
\text { Bacca }\end{array}$} & \multirow[t]{2}{*}{$\begin{array}{l}\text { Lesueur } \\
\text { coll. }\end{array}$} & $\mathrm{BB}$ & 2060 & $\begin{array}{l}\text { Unworked } \\
\text { block }\end{array}$ & $\begin{array}{l}\text { Polyhedral angular morphology. } \\
\text { Granular grey-banded texture in a } \\
\text { black matrix. }\end{array}$ & SC \\
\hline & & BT & 121.3 & $\begin{array}{l}\text { Tested } \\
\text { block }\end{array}$ & Polyhedral angular morphology. & SA \\
\hline Foce Zonza & Pasquet & $95-195$ & 69.2 & Flake & $\begin{array}{l}\text { Large shaping flake. Internal fracture } \\
\text { plane. Very finely granulated. Excellent } \\
\text { knapping quality. }\end{array}$ & SC \\
\hline $\begin{array}{l}\text { Teghja di } \\
\text { Donna }\end{array}$ & Gavini coll. & Tegh-1 & 2540 & $\begin{array}{l}\text { Broken } \\
\text { block }\end{array}$ & $\begin{array}{l}\text { Fragment of a block of no more than } \\
15 \mathrm{~kg} \text { initially. No patina. Presence of a } \\
\text { perlitic matrix. }\end{array}$ & Lipari? \\
\hline \multirow[t]{8}{*}{ Tivulaghju } & \multirow[t]{7}{*}{$\begin{array}{l}\text { Tramoni } \\
\text { et al., } 2007\end{array}$} & $1(7)^{*}$ & 385 & $\begin{array}{l}\text { Unworked } \\
\text { block }\end{array}$ & $\begin{array}{l}\text { Polyhedral angular morphology. } \\
\text { Granular grey-banded texture in a } \\
\text { black matrix. }\end{array}$ & $\mathrm{SA}$ \\
\hline & & $2(5)$ & 313 & & $\begin{array}{l}\text { Polyhedral angular morphology. } \\
\text { Granular grey-banded texture in a } \\
\text { black matrix. }\end{array}$ & SA \\
\hline & & $3(6)$ & 227 & & $\begin{array}{l}\text { Polyhedral angular morphology. Black } \\
\text { homogeneous texture. Good knapping } \\
\text { quality. }\end{array}$ & SC \\
\hline & & $4(3)$ & 142 & $"$ & $\begin{array}{l}\text { Polyhedral angular morphology. } \\
\text { Grey-banded texture in a black matrix }\end{array}$ & SA \\
\hline & & $5(4)$ & 110.5 & $"$ & $\begin{array}{l}\text { Polyhedral angular morphology. Black } \\
\text { homogeneous coarsely grained texture. } \\
\text { Brown/red coloured contact surface. }\end{array}$ & $\mathrm{SC} /(\mathrm{SB} 2 ?)$ \\
\hline & & $6(2)$ & 466 & $"$ & $\begin{array}{l}\text { Angular/subangular morphology. } \\
\text { Distinct banding. Smooth adamantine } \\
\text { luster. }\end{array}$ & SC \\
\hline & & $7(1)$ & 439 & $"$ & $\begin{array}{l}\text { Polyhedral angular morphology. } \\
\text { Granular grey-banded texture in a } \\
\text { black matrix. }\end{array}$ & SA \\
\hline & Tramoni & 8 & 201 & $"$ & $\begin{array}{l}\text { Angular subdiscoidal morphology. } \\
\text { Grey-banded texture in a black matrix. }\end{array}$ & SA \\
\hline Vasculacciu & $\begin{array}{l}\text { Milleliri } \\
\text { coll. }\end{array}$ & Vas-Bl1 & 207 & $\begin{array}{l}\text { Fragmented } \\
\text { block } \\
\text { Unworked } \\
\text { block }\end{array}$ & $\begin{array}{l}\text { Polyhedral angular morphology. } \\
\text { Granular grey-banded texture in a dark } \\
\text { matrix. Smooth dark-grey banded } \\
\text { texture. Good quality. Contains } \\
\text { phenocrystals. }\end{array}$ & SC \\
\hline
\end{tabular}

Origin of samples: private collections Gavini, Lesueur, Milleliri, Pasquet.

* The Vasculaghju samples 1-7 come from the same area (sector 1 ) of the site. The reference numbers in parenthesis refer to Tramoni et al. (2007).

dating from the Basian to the final Neolithic is uncertain, whereby we cannot exclude a historic date for this piece.

\section{PIXE analysis and sourcing}

The blocks' raw material provenance was deduced from their elemental compositions as obtained by ion beam analysis using the Accélérateur Grand Louvre d'Analyse Élémentaire (AGLAÉ) at the Laboratoire du Centre de Recherche et de Restauration et des Musées de France (LC2RMF, UMR171, Paris) (Fig. 4). The analyses were undertaken by the non-destructive technique of particle induced X-ray emission (PIXE) using an external $3 \mathrm{MeV}$ proton beam of approximately 50 micron diameter scanned over a sample surface of nearly one millimeter square. Three such measurements were made in different points of each block in order to take into account possible heterogeneities within the raw material. The fluorescence X-rays emitted by the obsidian samples were collected by two $\mathrm{Si}(\mathrm{Li})$ detectors, with the data treated by the 2000 version of the GUPIX software (Campbell et al., 2000). Details about experimental procedures, spectra processing and data treatments are described elsewhere (Bellot-Gurlet et al., 2005, 2008; Le Bourdonnec et al., 2005, 2010b; Lugliè et al., 2007).

The fifteen element contents determined for each block are reported in Table 2 (top). Clearly more than one type of composition is represented in this group of material. Apart from $\mathrm{Ga}$, significant variations are observed in all other elements contents, the most striking being with regard to $\mathrm{Sr}$ and $\mathrm{Zr}$. These compositions exclude a southern Tyrrhenian origin, as shown by a bivariate diagram when comparing the $\mathrm{Zr}$ and $\mathrm{Rb}$ contents of these blocks to those of geological samples from the four potential West Mediterranean island-sources analyzed by the same technique (Fig. 5). This diagram also suggests that at least two types of Sardinian sources are represented among the blocks. A comparison with the average PIXE compositions of the four Sardinian obsidian types (Table 2, bottom) shows that the blocks cannot be of the SB1 type, due in particular to their 


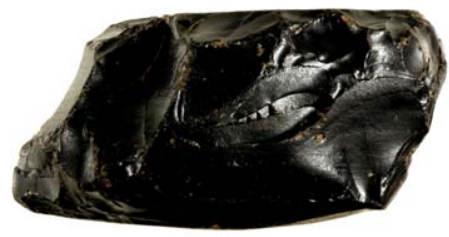

1

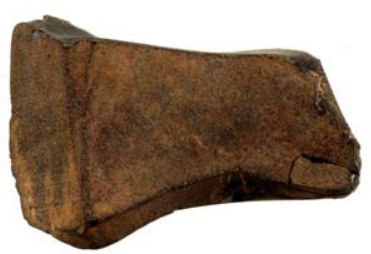

3

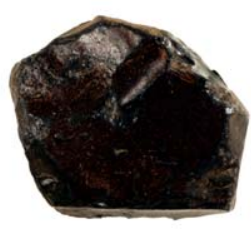

5

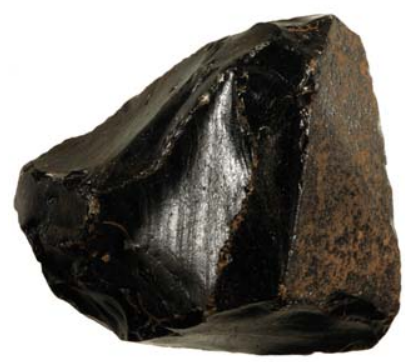

7

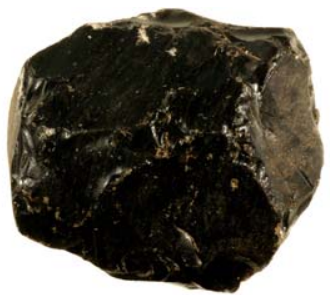

2

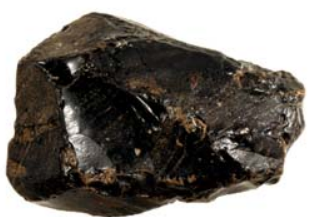

4

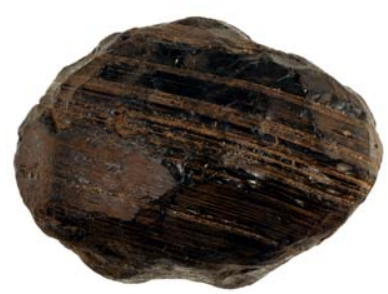

6

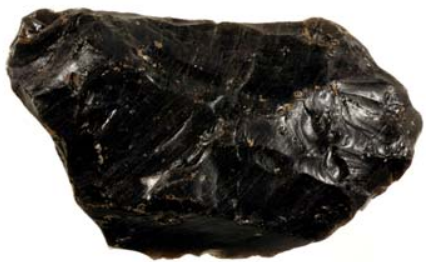

8

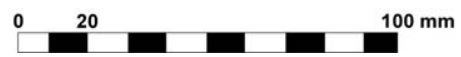

Fig. 2. Obsidian blocks from the Tivulaghju site. Reference numbers as in Tables 1 and 2.

Fig. 2. Blocs d'obsidienne du site de Tivulaghju. Les codes de références sont ceux des Tableaux 1 et 2.

$\mathrm{Mn}, \mathrm{Sr}$ and $\mathrm{Zr}$ contents, or of the SB2 type on the basis of their $\mathrm{Zn}$ and $\mathrm{Zr}$ contents. This leaves only two possibilities, namely the SA and SC types, as confirmed by a 3D diagram based on the samples $\mathrm{Zr}$, Zn and Mn contents (Fig. 6). The PIXE analysis confirms the visual type attributions proposed for 11 blocks in Table 1 , and by extent establishes firmly the Lipari provenance of the Teghja di Donna piece, and resolves the only uncertainty left by the macroscopic appearance about the sample from Tivulaghju 5 in favour of the SC type.

The primary sources of the SA and SC obsidians are located in the southern and the north-eastern parts of the Sardinian Monte Arci volcanic massif (Fanti and Lugliè, 2010; Lugliè et al., 2006). While the distribution of the SA obsidian tends to be spatially limited to the immediate vicinity of the source (Fanti and Lugliè, 2010), SC obsidians blocks and cobbles of sizes and qualities convenient for knapping are dispersed over greater distances, into the plains surrounding the massif on its eastern, southern and south-western parts, implying in the most extreme cases a colluvial/fluvial transportation of nearly $40 \mathrm{~km}$. The morphologies of these raw products vary with distance from the primary sources, from angular to more or less rounded shapes, while their sizes decrease accordingly. In addition, due to the time spans spent in river terraces deposits, these 'secondary' source obsidians acquired a more or less developed cortex. Shape, size and the presence of cortex are therefore important parameters in visual sourcing studies of 'archaeological' SC obsidians (Lugliè et al., 2007, 2008, 2009). The size of our SC blocks from Corsica, 

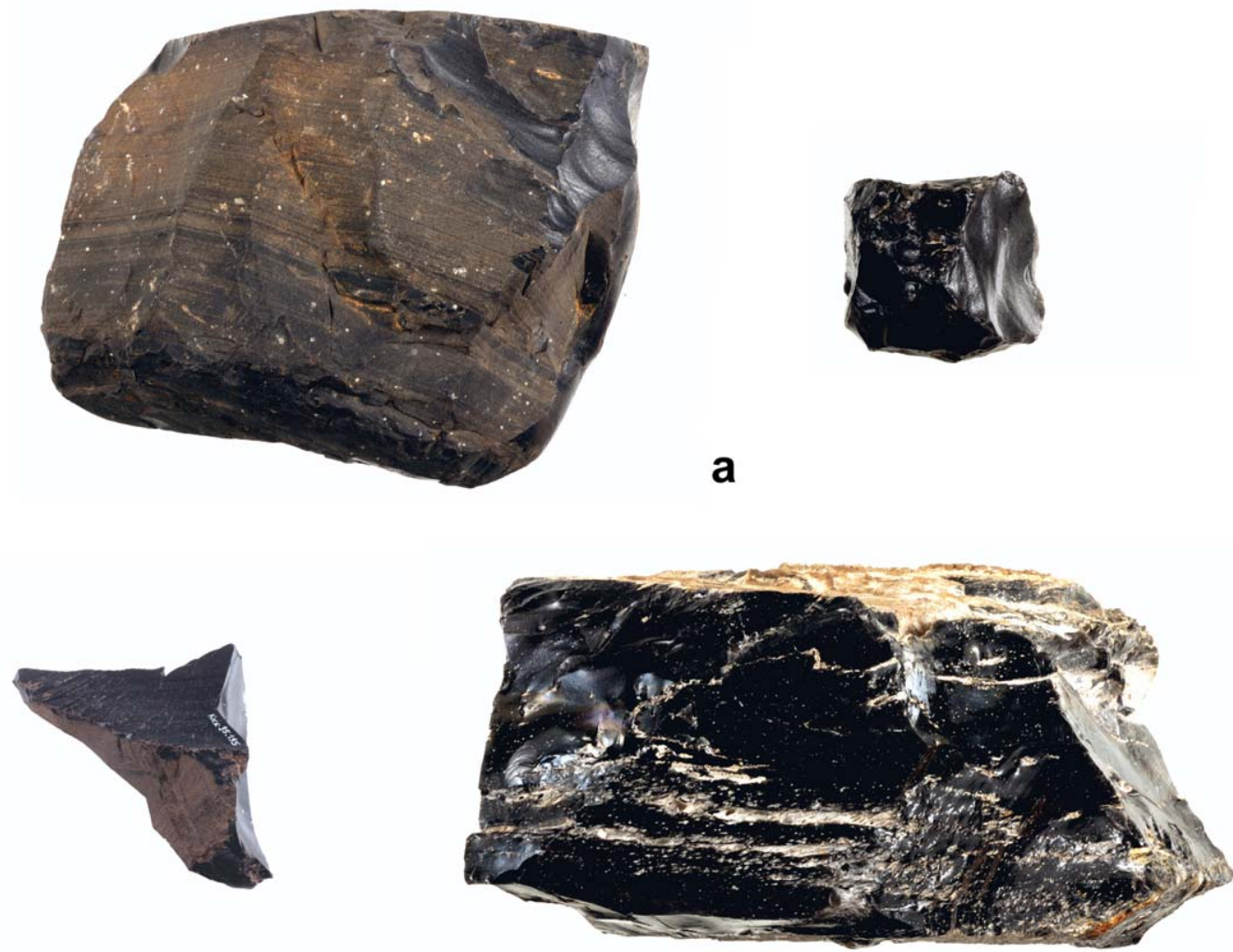

b

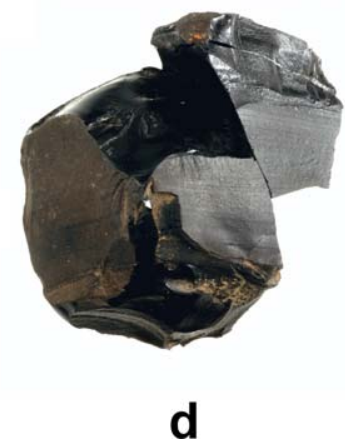

C

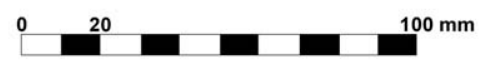

Fig. 3. Obsidian blocks from the Caselli-Bacca (a), Foce Zonza (b), Teghja di Donna (c) and Vasculacciu (d) sites

Fig. 3. Blocs d'obsidienne des sites de Caselli-Bacca (a), Foce Zonza (b), Teghja di Donna (c) et Vasculacciu (d).

with their sub-angular shape and very limited/absent cortex, suggests that they were acquired from the primary source or its associated nearby colluvial deposits. More precisely, while the SA blocks could only have come from the Conca'e Cannas small valley, those of the SC type are typical of the obsidians from the detrital deposits of the Niu'e Crobu-Sennixeddu slopes, below the primary outcrops of the Perdas Urias cliff (Pau territory, see Lugliè, 2003).

\section{Discussion}

During the Neolithic the lithic industries of Corsica relied for a large part on the use of non-local materials as flint and obsidian. This raises the question of these raw materials origins, of the form under which they were introduced in the island and of their mode of procurement. Until recently, obsidian provenance studies had been undertaken on material from no more than 15 sites (it is recorded at nearly 40 [Vaquer, 2006, 2007]) and even then usually involving only a small fraction of the total assemblage (Costa, 2006). These characterization studies suggested that with only a few exceptions these obsidians came from Sardinia, a pattern that has been further confirmed by a series of more recent analyses (Bressy et al., 2007, 2008; Le Bourdonnec et al., 2010a; Paolini-Saez et al., 2008). 
Table 2

PIXE analytical data.

Tableau 2

Données analytiques PIXE.

\begin{tabular}{|c|c|c|c|c|c|c|c|c|c|c|c|c|c|c|c|c|c|}
\hline $\begin{array}{l}\text { Site (blocks) /Source } \\
\text { (geological samples) }\end{array}$ & $\begin{array}{l}\text { Block sample/Data on } \\
\text { source samples }\end{array}$ & $\mathrm{Na}_{2} \mathrm{O}$ & $\mathrm{Al}_{2} \mathrm{O}_{3}$ & $\mathrm{SiO}_{2}$ & $\mathrm{~K}_{2} \mathrm{O}$ & $\mathrm{CaO}$ & $\mathrm{TiO}_{2}$ & $\mathrm{MnO}$ & $\mathrm{Fe}_{2} \mathrm{O}_{3}$ & $\mathrm{Zn}$ & $\mathrm{Ga}$ & $\mathrm{Rb}$ & $\mathrm{Sr}$ & $\mathrm{Y}$ & $\mathrm{Zr}$ & $\mathrm{Nb}$ & Type \\
\hline \multirow[t]{2}{*}{ Caselli-Bacca } & BB & 3.1 & 14.2 & 72.9 & 5.3 & 0.85 & 0.268 & 0.030 & 2.13 & 66 & 22 & 182 & 138 & 22 & 236 & 34 & SC \\
\hline & BT & 3.5 & 13.9 & 75.7 & 4.8 & 0.64 & 0.080 & 0.050 & 1.07 & 69 & 21 & 218 & 32 & 30 & 66 & 46 & SA \\
\hline Foce Zonza & $95-195$ & 2.6 & 15.2 & 73.2 & 5.4 & 0.93 & 0.281 & 0.028 & 1.44 & 55 & 20 & 167 & 147 & 22 & 224 & 29 & $\mathrm{SC}$ \\
\hline Teghja di Donna & Tegh-1 & 3.5 & 12.7 & 75.4 & 4.8 & 0.73 & 0.071 & 0.067 & 1.87 & 55 & 19 & 321 & 23 & 51 & 194 & 32 & Lipari \\
\hline \multirow[t]{8}{*}{ Tivulaghju } & $1(7)$ & 3.6 & 14.0 & 75.1 & 4.9 & 0.65 & 0.096 & 0.054 & 1.21 & 78 & 25 & 250 & 37 & 35 & 76 & 53 & SA \\
\hline & $2(5)$ & 2.9 & 14.6 & 75.0 & 4.9 & 0.66 & 0.115 & 0.054 & 1.26 & 75 & 25 & 231 & 40 & 36 & 75 & 49 & SA \\
\hline & $3(6)$ & 2.2 & 15.7 & 72.0 & 5.5 & 1.00 & 0.325 & 0.034 & 1.75 & 66 & 23 & 200 & 168 & 27 & 264 & 32 & SC \\
\hline & $4(3)$ & 3.2 & 13.9 & 75.4 & 5.0 & 0.63 & 0.093 & 0.055 & 1.18 & 78 & 24 & 247 & 31 & 36 & 80 & 50 & SA \\
\hline & $5(4)$ & 2.4 & 14.5 & 73.9 & 5.4 & 0.87 & 0.268 & 0.029 & 1.58 & 57 & 22 & 176 & 146 & 23 & 231 & 28 & SC \\
\hline & $06(2)$ & 2.3 & 14.9 & 72.9 & 5.5 & 0.95 & 0.332 & 0.033 & 1.72 & 59 & 20 & 159 & 146 & 22 & 207 & 30 & $\mathrm{SC}$ \\
\hline & $7(1)$ & 2.8 & 14.0 & 76.0 & 4.9 & 0.64 & 0.096 & 0.052 & 1.13 & 71 & 23 & 225 & 30 & 31 & 70 & 44 & SA \\
\hline & 8 & 2.7 & 14.2 & 75.3 & 4.9 & 0.66 & 0.108 & 0.059 & 1.35 & 84 & 27 & 278 & 37 & 36 & 84 & 52 & SA \\
\hline Vasculacciu & Vas-Bl1 & 3.6 & 14.3 & 73.3 & 5.4 & 0.89 & 0.266 & 0.030 & 1.46 & 54 & 21 & 160 & 138 & 23 & 207 & 24 & SC \\
\hline MDL & & 0.01 & 0.01 & 0.01 & 0.01 & 0.03 & 0.007 & 0.001 & 0.01 & 1 & 1 & 4 & 2 & 4 & 5 & 3 & \\
\hline \multicolumn{18}{|l|}{$\begin{array}{l}\text { Sardinian (Monte } \\
\text { Arci) obsidian } \\
\text { types* }\end{array}$} \\
\hline \multirow[t]{2}{*}{$\mathrm{SA}(n=8)$} & Average & 3.4 & 13.7 & 75.7 & 4.9 & 0.60 & 0.088 & 0.053 & 1.29 & 78 & 24 & 253 & 28 & 37 & 78 & 57 & \\
\hline & standard deviation & 0.1 & 0.1 & 0.1 & 0.1 & 0.01 & 0.006 & 0.002 & 0.06 & 4 & 1 & 14 & 4 & - & 8 & - & \\
\hline \multirow[t]{2}{*}{$\mathrm{SB} 1(n=6)$} & Average & 3.4 & 13.9 & 74.9 & 5.0 & 0.73 & 0.139 & 0.045 & 1.44 & 72 & 24 & 250 & 65 & na & 121 & na & \\
\hline & Standard deviation & 0.1 & 0.1 & 0.2 & 0.1 & 0.02 & 0.009 & 0.002 & 0.06 & 2 & 1 & 10 & 4 & & 6 & & \\
\hline \multirow{2}{*}{$\mathrm{SB} 2(n=10)$} & Average & 3.2 & 13.3 & 76.0 & 5.2 & 0.60 & 0.125 & 0.031 & 1.25 & 44 & 18 & 239 & 42 & 22 & 108 & 31 & \\
\hline & Standard deviation & 0.1 & 0.1 & 0.2 & 0.2 & 0.06 & 0.016 & 0.002 & 0.10 & 3 & 2 & 14 & 9 & 4 & 12 & - & \\
\hline \multirow[t]{2}{*}{$\mathrm{SC}(n=20)$} & Average & 3.1 & 14.4 & 73.6 & 5.3 & 0.93 & 0.286 & 0.030 & 1.74 & 61 & 22 & 179 & 148 & 24 & 241 & 33 & \\
\hline & Standard deviation & 0.1 & 0.2 & 0.2 & 0.1 & 0.10 & 0.033 & 0.001 & 0.13 & 4 & 1 & 10 & 19 & 2 & 23 & 5 & \\
\hline
\end{tabular}

Oxides and elements contents are given in weight per cent and ppm respectively; $\mathrm{MDL}=$ mean detection level; na = not analyzed.

"Le Bourdonnec et al., 2010b; $n=$ number of samples analyzed per Monte Arci obsidian type. 


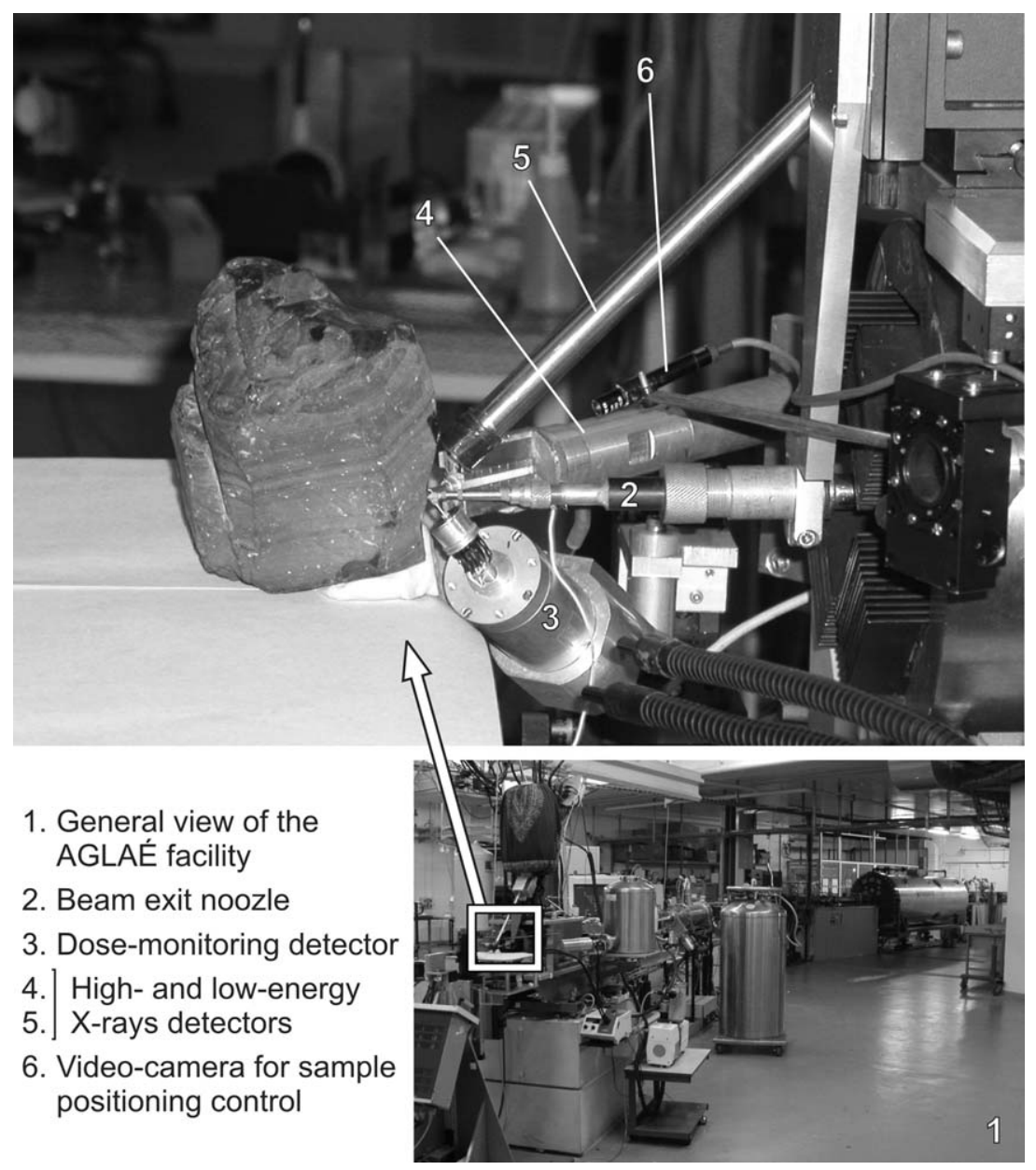

Fig. 4. Experimental set-up for the analysis of obsidian blocks (here those of Caselli-Bacca) at the AGLAE facility. The sample is exposed to the proton beam of a tandem Van de Graaf accelerator in the ambient room atmosphere after its exit off the machine vacuum through an ultra-thin $\left(0.1 \mu \mathrm{m}\right.$ thick) $\mathrm{Si}_{3} \mathrm{~N}_{4}$ window. A helium flux between the sample and this window lowers the atmosphere mean molar weight to limit absorption effects.

Fig. 4. Montage expérimental pour l'analyse d'un bloc d'obsidienne (ici celui de Caselli-Bacca) par PIXE à AGLAE. L'échantillon est exposé au flux de protons produit par un accélérateur Tandem Van de Graaf, après sa sortie de machine, au travers d'une fenêtre ultra-fine $\left(0,1 \mu \mathrm{m}\right.$ d'épaisseur) de Si ${ }_{3} \mathrm{~N}_{4}$. Un flux d'hélium entre l'échantillon et cette fenêtre diminue le numéro atomique moyen de l'atmosphère pour limiter les effets d'absorption.

From the 6th to the 3rd millennium $B C$ we have clear evidence of the SA, SB and SC Sardinian source materials being procured by Corsican communities, however the still limited data prevents a clear understanding of these different materials' spatio-temporal trends and relative abundance (Le Bourdonnec et al., 2010a). When the subtypes SB1 and SB2 are distinguished, as in some recent studies, it appears that in Corsica - as elsewhere - the SB1 type, of poor knapping quality, is only occasionally present (Lugliè et al., 2007, 2008, 2009). Outside of Sardinia, in particular on the Italian peninsula, the high relative frequency of the SB2 type found in Early Neolithic contexts (6th-beginnings of the 5th millennium BC) diminishes significantly from the late Middle Neolithic (second half of the 5th millennium BC). It is therefore not surprising that among the 13 blocks analyzed, twelve are of Sardinian origin, coming specifically from the two major sources exploited at this time, SA and SC. The provenance of the other obsidian artefacts from the same sites, although previously poorly documented, also points to a Sardinian origin. This was the case for two obsidian artifacts from Tivulaghju, found to be of the SC type (Magdeleine and Ottaviani, 1986), while the 44 pieces analyzed from Vasculaghju, three came from SA, one from SB1, 11 from SB2 and 26 from SC (Hallam et al., 1976; Le Bourdonnec et al., 2010a).

The presence of one block from Lipari (the visual characterization confirmed by elemental analysis) constitutes an exceptional piece in southern Corsica. This unexpected occurrence was a surface find assigned a final Neolithic date on the basis of associated finds. During this period, Lipari obsidian was mainly used by communities on the Italian peninsula, especially those of the Pouilles and Tavoliere areas and Paduan plain, and to a lesser extent by the peoples of Tuscany and the Tyrrhenian coast (Lugliè, 2009; Tykot, 1996; Vaquer, 2007). Corsica and Sardinia, with their closely linked Neolithic cultures, were not directly connected to the exchange networks responsible for the 


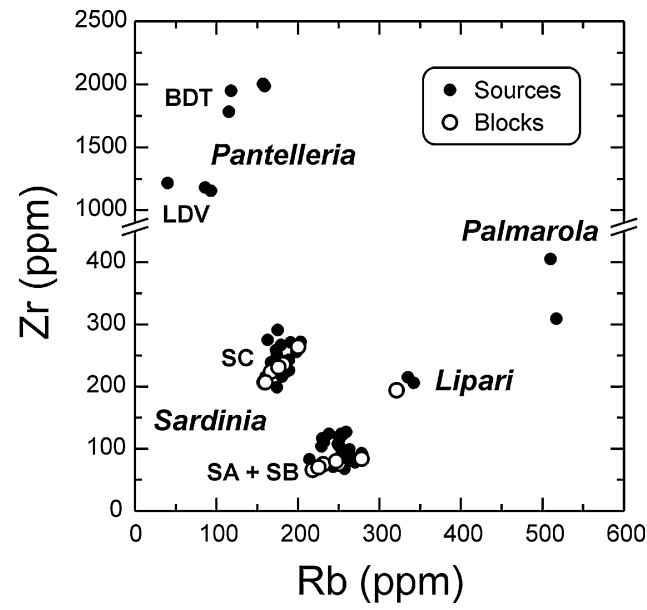

Fig. 5. Bivariate diagram comparing the $\mathrm{Zr}$ and $\mathrm{Rb}$ contents in the Corsican blocks and in obsidians from the western Mediterranean island-sources (PIXE data on geological obsidians from Lugliè et al., 2007; Lugliè et al., 2008; Lugliè et al., 2009; Mulazzani et al., 2010; Poupeau et al., 2000).

Fig. 5. Diagramme comparant les teneurs en $\mathrm{Zr}$ et $\mathrm{Rb}$ des blocs corses avec celles d'obsidiennes des îles-sources de Méditerranée occidentale (les données PIXE pour les échantillons géologiques sont celles de Lugliè et al., 2007, 2008, 2009; Mulazzani et al., 2010; Poupeau et al., 2000).

circulation of Lipari obsidian. If the presence of two artefacts of Lipari obsidian in the north-western Corsica site of A Fuata suggests a marginal contact with this network (Le Bourdonnec et al., 2010a), the significance of the Lipari block at Teghja di Donna is unclear. This quite heterogeneous block, replete with phenocrysts and bubbles, is of very poor knapping quality and therefore of no apparent technological/economic interest. In contrast, the only other obsidians known to have circulated far beyond Lipari tend to be of the best glassy, homogeneous and transparent quality. Moreover, these glassy obsidians never circulated

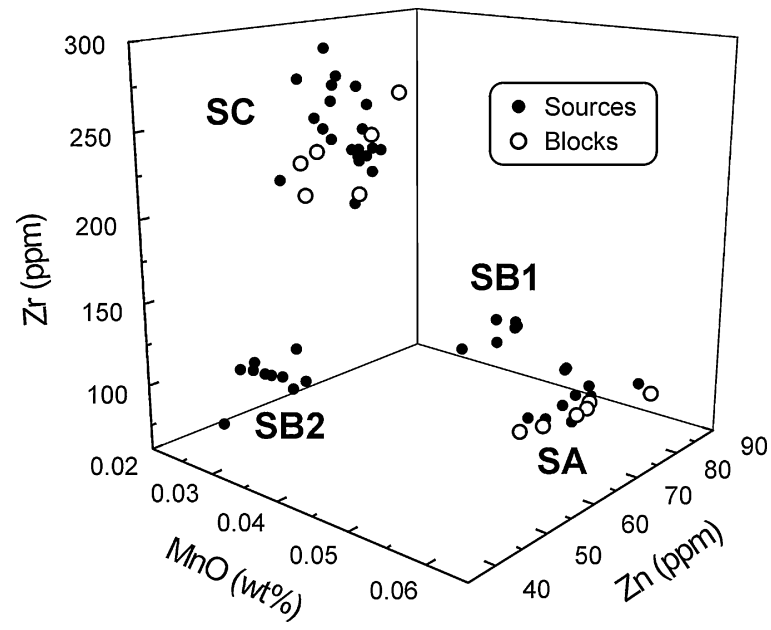

Fig. 6. 3D diagram comparing the $\mathrm{Zr}$, $\mathrm{Zn}$ and $\mathrm{Mn}$ (as $\mathrm{MnO}$ ) contents in the Corsican blocks and in obsidians from the Sardinian Monte Arci (PIXE data on geological obsidians as in Fig. 5).

Fig. 6. Diagramme comparant les teneurs en $\mathrm{Zn}, \mathrm{Zr}$ et $\mathrm{Mn}$ (cette dernière exprimée en oxyde $\mathrm{MnO}$ ) dans les blocs corses avec celles des obsidiennes sardes du Monte Arci (données PIXE pour les échantillons géologiques comme sur la Fig. 5). as unworked blocks, either to Calabria in the Early Neolithic or elsewhere from the Middle Neolithic. The recovery of a Lipari obsidian block from the Neolithic site of Teghja di Donna thus remains anomalous, a chance find that made its way to Corsica by unknown means.

All the blocks found to date (Table 1 ) are unfortunately surface finds, whose arrival on Corsica is of uncertain date. The I Caselli and Foce contexts suggest a 4th millenium BC date, with the abundant associated surface finds relating to the recent Basian Neolithic (Pasquet, 1979; Tramoni, 2000), a period during which obsidian was still one of the main raw materials used in Corsica (Bailloud, 1969; Camps, 1988; Vaquer, 2006). However, at Foce there is evidence of an earlier occupation of the 5 th millennium BC. At Tivulaghju and Vasculacciu the blocks were collected during systematic field studies. The Middle Neolithic age of the nearby/associated structures, inferred from their lithic typology and ceramic style, has been confirmed by ${ }^{14} \mathrm{C}$ dating and is in agreement generally with the appearance of megalithism on the island (Tramoni et al., 2007).

Throughout the Neolithic, Corsican populations were entirely dependent on Sardinia for their supply of 'good quality' lithic raw materials, specifically obsidian and flint. In the ancient Cardial Neolithic sites of southern Corsica, where obsidian formed only a minority component, the presence of cortical products and of all steps of the chaîne opératoire, as in Basi (Bailloud, 1969), Campu Stefanu (Cesari et al., 2011) and Renaghju (Bressy et al., 2003; D'Anna et al., 2001), suggests that from the 6th millenium $\mathrm{BC}$ onwards these people were 'importing' obsidian in the form of raw blocks and/or partly tested blocks. As such, it comes as no great surprise that eventually archaeologists might recover examples of actual raw blocks, with the finds at Tivulaghju and Vasculaciu substantiating this expectation for the Middle Neolithic of the 5th millennium BC (Tramoni et al., 2004, 2007).

At present, the discussions concerning the history of obsidian circulation in Corsica and the mode(s) by which these exotic raw materials were introduced to the island are hampered by two major obstacles; firstly there is a lack of precise stratigraphic context for the samples, while we also lack radiometric dating for the obsidian-bearing sites/cultural horizons, and their overall integration within a reliable chrono-cultural reference frame. Future sourcing studies need to focus on well-documented sites/samples. Secondly, obsidian-sourcing studies have hitherto usually been limited to a few samples per assemblage, with little discussion as to the sampling strategy and/or the technotypological specifics of the artifacts ('samples'). Hence questions remain as to how representative of direct procurements/exchanges these data are. The recent advances in physicochemical methods of obsidian characterization and their association with visual sourcing should allow the sourcing of entire assemblages.

\section{Conclusion}

The provenance of the only 13 raw obsidian blocks thus far known from Corsica was determined both visually and by non-destructive ion beam analysis (PIXE). Twelve of these blocks were unworked, one had only been tested and 
all were surface finds. Twelve blocks were associated with Neolithic remains that should date them to the 4th millennium BC (although one might possibly relate to the 5th millennium BC) and were sourced to Sardinia. In eleven of these twelve cases the visual source attribution was confirmed by elemental analysis. In the remaining case, a visually ambiguous attribution was resolved by the PIXE. Six blocks were found to belong to the SA and SC types respectively of the Sardinian Monte Arci volcanic complex. One unworked block had been, from its macroscopic appearance, attributed a Lipari island origin, an attribution confirmed by elemental analysis. However this sample is of uncertain archaeological significance.

The presence of raw blocks of Sardinian obsidian in southern Corsica was by no means unexpected, as during the Middle Neolithic this volcanic glass was used extensively by island communities, and because entire reduction sequences were attested amongst some of these Corsican assemblages. The sourcing of these blocks to the SA and SC Monte Arci types also corresponds to the period of these sources' greatest use (Lugliè, 2009).

This work confirms the pertinence in western Mediterranean obsidian provenance studies of the association of visual and instrumental determinations. Taking into account recent advances in instrumental obsidian sourcing this approach will allow the treatment of entire assemblages. Thus not only the dynamics of Sardinian obsidian circulation and use might be better understood in the Tyrrhenian and central Mediterranean areas, but rare events, as the presence of Lipari or Palmarola obsidians in Corsica, have a better chance of being detected. Provenance studies of artifacts from sites located on the margins of known 'influence zones' of the various western Mediterranean obsidian sources could also serve as a means of recovering evidence for the occasional contact between members of different socio-economic systems.

\section{Acknowledgements}

The authors are indebted to the prospectors who provided them with some of the blocks analyzed here, F. Gavini (Teghja di Donna site), Fr. Lesueur (I Caselli), S. Milleliri(Vasculacciu) and to the AGLAE facility team members of the Laboratoire du Centre de Recherche et de Restauration des Musées de France LC2RMF UMR171 (Paris) Thomas Calligaro, Brice Moignard, Laurent Pichon and the late Joseph Salomon. They wish to thank Tristan Carter for his expert revision of the English. The analytical part of this work was partly funded by the GdR 3174 CNRS "ChimARC" project. Group meetings and field works were supported by grants from the Collectivité Territoriale de Corse and the French Ministère de la Culture (Service Régional de l'Archéologie de Corse).

\section{References}

Ameziane-Federzoni, N., 2007a. Approvisionnement et diffusion de la rhyolite au VIe et Ve millénaires avant J.-C. dans le Nord de la Corse. In: Tozzi, C., Weiss, M.C. (Eds.), Préhistoire et protohistoire de l'aire tyrrhénienne; preistoria e protostoria dell'area tirrenica. Felici Editore, Ghezzano, pp. 223-228.
Ameziane-Federzoni, N, 2007b. Diffusion de la rhyolite au Néolithique ancien et moyen dans le Nord de la Corse: premiers résultats. In: Fouéré, P., Chevillot, C., Courtaud, P., Ferullo, O., Leroyer, C. (Eds.), Paysages et Peuplements: aspects Culturels et Chronologiques en France Méridionale ; actualité de la Recherche, Actes des $6^{\mathrm{e}}$ Rencontres Méridionales de Préhistoire Récente, Périgueux, octobre 14-16 2004, Préhistoire du Sud-Ouest, Supplément 11, Cressensac, pp. 339-345.

Arias, A., Oddone, M., Bigazzi, G., Di Muro, A., Principe, C., Norelli, P., 2006. New data for the characterization of Milos obsidians. J. Radioanalytical and Nuclear Chemistry 268, 371-386.

Atzeni, E., 1966. L'Abri sous roche D' du village préhistorique de Filitosa (Sollacaro, Corse). Congrès Préhistorique de France. XVIII ${ }^{\mathrm{e}}$ session, Ajaccio, 169-192.

Bailloud, G., 1969. Fouille d'un habitat néolithique et torréen à Basi, Serradi-Ferro. Corse. Bull Soc. Préhist. Fr. 66, 367-384.

Bellot-Gurlet, L., Poupeau, G., Salomon, J., Calligaro, T., Moignard, B., Dran, J.C., Barrat, J.A., Pichon, L., 2005. Obsidian provenance studies in archaeology: A comparison between PIXE, ICP-AES and ICP-MS. Nuclear Instruments and Methods In Physics Research Section B 240, 583-588.

Bellot-Gurlet, L., Dorighel, O., Poupeau, G., 2008. Obsidian provenance studies in Colombia and Ecuador: obsidian sources revisited. J. Archaeol. Sci. 35, 272-289.

Bigazzi, G., Radi, G., 1998. Prehistoric exploitation of obsidian for tool making in the Italian peninsula: a picture from a rich fission-track data-set. Proceedings of the XIII International Congress of Prehistoric and Protohistoric Sciences, Forlì, Italy, September 8-14 1996, 149-156.

Bigazzi, G., Oddone, M., Radi, G., 2005. The Italian obsidian sources. Archeometriai Mühely 1, 1-13.

Bressy, C., Bellot-Gurlet, L., D’Anna, A., Pelletier, D., Tramoni, P., 2003. Provenance et gestion des matières premières lithiques du site néolithique ancien cardial de Renaghju (Sartène, Corse-du-Sud). In: Surmely, F. (Ed.), Actes de la Table Ronde Internationale sur Les Matières Premières Lithiques en Préhistoire, Aurillac, France, June 20-22 2002, Préhistoire du Sud-Ouest, Supplément 5, pp. 71-79.

Bressy, C., Bellot-Gurlet, L., Convertini, F., D’Anna, A., Guendon, J.L., Pelletier, D., Tramoni, P., 2007. Matières premières et circulation des matériaux dans le Néolithique ancien de Renaghju (Sartène, Corsedu-Sud). In: D’Anna, A., Cesari, J., Ogel, L., Vaquer, J. (Eds.), Corse et Sardaigne préhistoriques, Relations et Échanges dans le Contexte Méditerranéen, Actes des Congrès Nationaux des Sociétés Historiques et Scientifiques, $128^{\mathrm{e}}$ Bastia, 2003, Documents préhistoriques n 22, pp. 87-98.

Bressy, C.S., D’Anna, A., Poupeau, G., Le Bourdonnec, F.X., Bellot-Gurlet, L., Leandri, F., Tramoni, P., Demouche, F., 2008. Chert and obsidian procurement of three Corsican sites during the 6th and 5th millennium BC. C. R. Palevol 7, 237-248.

Campbell, J.L., Hopman, T.L., Maxwell, J.A., Nejedly, Z., 2000. The Guelph PIXE software package III: Alternative proton database. Nuclear Instruments and Methods in Physics Research Section B 170, 193-204.

Camps, G., 1988. Préhistoire d'une île. Les origines de la Corse. Errance, Paris, 284 p.

Cann, J.R., Renfrew, C., 1964. The characterization of obsidian and its application to the Mediterranean region. Proceedings of the Prehistoric Society $30,111-133$

Cesari, J., Leandri, F., Pêche-Quilichini, K., Demouche, F., Bressy-Leandri, C., Nebbia, P., 2011. Note préliminaire sur l'habitat pré- et protohistorique de Campu Stefanu (Sollacaro, Corse-du-Sud). In: Sénépart, I., Perrin, T., Thirault, E., Bonnardin, S. (Eds.), Actes des $8^{\mathrm{e}}$ Rencontres Méridionales de Préhistoire Récente, Marseille, November 7-8 2008, Marges, frontières et transgressions - actualité de la Recherche, Éd. Archives d'Écologie Préhistorique, Toulouse, pp. 265-281.

Costa, L.J., 2006. Récents acquis sur la circulation préhistorique de l'obsidienne en Corse. Bull. Soc. Préhist. Fr. 103, 71-85.

Costa, L.J., Ottaviani-Spella, M.M., Nicolle, F., Berlinghi, A., 2002. Contribution à l'étude des modalités d'exploitation des rhyolites en Corse : l'exemple des filons du Monte d'Oro (Vivario, Haute-Corse). Bull. Soc. Préhist. France 99, 785-791.

D’Anna, A., Marchesi, H., Tramoni, P., Demouche, F., Gilabert, C., 2001. Renaghju (Sartène, Corse-du-Sud), un habitat de plein air néolithique ancien en Corse. Bull. Soc. Préhist. France 98, 431-444.

Fanti, L., Lugliè, C., 2010. Sulle tracce della "vera" sorgente: analisi dei depositi del gruppo geo-chimico SA. In: Lugliè, C. (Ed.), L'ossidiana del Monte Arci nel mediterraneo. Nuovi apporti sulla diffusione, sui sistemi di produzione e sulla loro cronologia, Atti del $5^{\circ}$ Convegno Internazionale, Pau, Italia, June 28-30 2008, Nur, Ales. , pp. 53-70.

Grosjean, R., 1961. Chroniques de l'association archéologique de la Corse. L'activité archéologique en 1960, compte rendu de la cam- 
pagne de fouilles et de recherches préhistoriques. Études corses 1 , 29-32.

Grosjean, R., Liegeois, L., 1964. Les coffres mégalithiques de la région de Porto-Vecchio. L'Anthropologie 68, 527-548.

Hallam, B.R., Warren, S.E., Renfrew, C., 1976. Obsidian in the western Mediterranean: characterisation by neutron activation analysis and optical emission spectrometry. Proceedings of the Prehistoric Society $42,85-110$.

Lanfranchi, F., 1980. L'obsidienne préhistorique corso-sarde : les échanges et les axes de circulation. Bull. Soc. Préhist. France 77, 115-122.

Lanfranchi, F., 1986. Inventaire des monuments dolméniques de la Corse. École des Hautes Études en Sciences Sociales. Toulouse, 717p.

Le Bourdonnec, F.X., Delerue, S., Dubernet, S., Moretto, P., Calligaro, T., Dran, J.C., Poupeau, G., 2005. PIXE characterization of western Mediterranean and Anatolian obsidians and Neolithic provenance studies. Nuclear Instruments and Methods in Physics Research Section B 240, 595-599.

Le Bourdonnec, F.X., Bontempi, J.M., Marini, N., Mazet, S., Neuville, P.F., Poupeau, G., Sicurani, J., 2010a. SEM-EDS characterization of western Mediterranean obsidians and the Neolithic site of A Fuata (Corsica). J. Archaeol. Sci. 37, 92-106.

Le Bourdonnec, F.X., Poupeau, G., Lugliè, C., 2010b. The Monte Arci (Sardinia, western Mediterranean) obsidians: characterization by multivariate analysis from SEM-EDS, EMP-WDS and PIXE elemental compositions. In: Lugliè, C. (Ed.), L'ossidiana del Monte Arci nel mediterraneo. Nuovi apporti sulla diffusione, sui sistemi di produzione e sulla loro cronologia, Atti del $5^{\circ}$ Convegno Internazionale, Pau, Italia, June 28-30 2008. Nur, Ales, pp. 13-28.

Lugliè, C., 2003. First report on the study of obsidian prehistoric workshops in the eastern side of Monte Arci (Sardinia). In: Surmely, F. (Ed.), Actes de la Table Ronde Internationale sur Les Matières Premières Lithiques en Préhistoire, Aurillac, France, June 20-22 2002, Préhistoire du SudOuest, Supplément 5, pp. 207-209.

Lugliè, C., 2009. L'obsidienne néolithique en Méditerranée occidentale. In: Moncel, M.H., Fröhlich, F. (Eds.), L'Homme et le précieux. Matières Minérales Précieuses de la Préhistoire à Aujourd'hui, BAR International Series 1934. John and Erica Hedges Ltd, Oxford, pp. 213-224.

Lugliè, C., Le Bourdonnec, F.X., Poupeau, G., Bohn, M., Meloni, S., Oddone, M., Tanda, G., 2006. A map of the Monte Arci (Sardinia Island, western Mediterranean) obsidian primary to secondary sources. Implications for Neolithic provenance studies. C. R. Palevol 5, 995-1003.

Lugliè, C., Le Bourdonnec, F.X., Poupeau, G., Atzeni, E., Dubernet, S., Moretto, P., Serani, L., 2007. Early Neolithic obsidians in Sardinia (western Mediterranean): the Su Carroppu case. J. Archaeol. Sci. 34, 428-439.

Lugliè, C., Le Bourdonnec, F.X., Poupeau, G., Congia, C., Moretto, P., Calligaro, T., Sanna, I., Dubernet, S., 2008. Obsidians in the Rio Saboccu (Sardinia, Italy) campsite: provenance, reduction and relations with the wider Early Neolithic Tyrrhenian area. C. R. Palevol 7, 249-258.

Lugliè, C., Congia, C., Le Bourdonnec, F.X., Bohn, M., Dubernet, S., Moretto, P., Sanna, I., Poupeau, G., 2009. Obsidian economy in the Rio Saboccu open-air Early Neolithic site (Sardinia). In: Sternke, F., Costa, L.J., Eigeland, L. (Eds.), Non-flint Raw Material Use in Prehistory: Old Prejudices and New Directions, Proceedings of the XVth Congress of the International Union of the Prehistoric and Protohistoric Sciences, BAR International Series 1939. Archaeopress, Oxford, pp. 203-215.
Magdeleine, J., Ottaviani, J.C., 1986. L'abri préhistorique de Strette. Bull. Soc. Sciences Historiques et Naturelles de la Corse 650, 61-90.

Marini, N., de Francesco, A.M., Bocci, M., Bressy, C., Gratuze, B., 2007. Costa di u Monte - du Néolithique à l'Âge du Fer sur la côte orientale corse : résultats de fouilles et provenance de vestiges. In: Tozzi, C., Weiss, M.C. (Eds.), Preistoria e Protostoria dell'Area Tirrenica. Felici Editore, Ghezzano, pp. 35-42.

Mulazzani, S., Le Bourdonnec, F.X., Belhouchet, L., Poupeau, G., Zoughlami, J., Dubernet, S., Tufano, E., Lefrais, Y., Khedhaier, R., 2010. Obsidian from the Epipalaeolithic and Neolithic eastern Maghreb. A view from the Hergla context (Tunisia). J. Archaeol. Sci. 37, 2529-2537.

Paolini-Saez, H., Le Bourdonnec, F.X., Poupeau, G., Bressy, C., OttavianiSpella, M.M., Pereira, E., Tramoni, P., Berlinghi, A., Lorenzo, S., Topi Pinnuti, I., Salotti, M., 2008. A Teppa di U Lupinu : étude de provenance du mobilier des hommes établis a Santu-Petru-di-Tenda (HauteCorse) au Néolithique moyen. Bull. Soc. Sciences Historiques et Naturelles de la Corse 724-725, 115-144.

Pasquet, A., 1979. Contribution à l'Atlas Préhistorique de la région de Porto-Vecchio. Archeologia Corsa 4, 53-81.

Poupeau, G., Bellot-Gurlet, L., Brisotto, V., Dorighel, O., 2000. Nouvelles données sur la provenance de l'obsidienne des sites néolithiques du Sud-Est de la France. C. R. Acad. Sci. Paris Ser. IIa 330, 297-303.

Salotti, M., Bellot-Gurlet, L., Courtois, J.Y., Dubois, J.N., Louchart, A., Mourer-Chauvire, C., Oberlin, C., Pereira, E., Poupeau, G., Tramoni, P., 2000. La fin du Pléistocène supérieur et le début de l'Holocène en Corse : apports paléontologique et archéologique du site de Castiglione (Oletta, Haute-Corse). Quaternaire 11, 219-230.

Tramoni, P., 2000. Recherches récentes sur les habitats de plein air en Corse: l'exemple de la région de Porto-Vecchio. Actes des 3e Rencontres Méridionales de Préhistoire Récente, Toulouse, November 1998, Archives d'Écologie Préhistorique. Toulouse, 109-118.

Tramoni, P., D’Anna, A., Guendon, J.L., Orsini, J.B., Pinet, L., 2003. Vasculacciu: une grande nécropole mégalithique du Sud de la Corse. Études Corses 56, 1-28.

Tramoni, P., D’Anna, A., Pinet, L., Guendon, J.L., Orsini, J.B., 2004. La nécropole mégalithique de Vasculacciu (Figari, Corse-du-Sud). In: Dartevelle, H. (Ed.), Auvergne et Midi - Actualité de la recherche, Actes des $5^{e}$ Rencontres Méridionales de Préhistoire Récente, Clermont-Ferrand (Puy-de-Dôme), November 8-9 2002. Préhistoire du Sud-Ouest. , pp. 523-536.

Tramoni, P., D’Anna, A., Pasquet, A., Milanini, J.L., Chessa, R., 2007. Le site de Tivulaghju (Porto-Vecchio, Corse-du-Sud) et les coffres mégalithiques du Sud de la Corse, nouvelles données. Bull. Soc. Préhist. France 104, 245-274.

Tykot, R.H., 1996. Obsidian Procurement and Distribution in the Central and Western Mediterranean. J. Mediterranean Archaeology 9, 39-82.

Vaquer, J., 2006. La diffusion de l'obsidienne dans le Néolithique de Corse, du Midi de la France et de Catalogne. XXXIX Riunione Scientifica del I.I.P.P. "Materie prime e scambi nella preistoria italiana nel cinquantenario della fondazione dell'Istituto Italiano di Preistoria e Protostoria", IIPP. Firenze, November 25-27 2004, 485-498.

Vaquer, J., 2007. Le rôle de la zone nord-tyrrhénienne dans la diffusion de l'obsidienne en Méditerranée nord-occidentale au Néolithique. Corse et Sardaigne préhistoriques : relations et échanges dans le contexte méditerranéen, Comité des Travaux historiques et scientifiques. Paris, 99-119. 